\title{
Zoological terms in the human histological nomenclature Terminologia Histologica. What we think, what we know, and what we think we know
}

\author{
Ivan Varga ${ }^{1} \cdot$ Luboš Danišovič $^{2} \cdot$ David Kachlík $^{3} \cdot$ Radoslav Beňuš $^{4} \cdot$ Martin Klein $^{1}$
}

Received: 8 July 2019 / Accepted: 2 September 2019 / Published online: 9 September 2019

(C) Institute of Zoology, Slovak Academy of Sciences 2019

\begin{abstract}
Terminology in morphological and zoological sciences is enormously important. Proper denomination of individual structures of the animal / human body from the microscopic point of view has an irreplaceable role in unambiguous understanding and communication among scientists regardless of their field of expertise. The year 2008 can be considered a crucial year in the developing of internationally accepted histological terminology, because it was the year when the first internationally renowned human histology nomenclature Terminologia Histologica was published. The current version of the Terminologia Histologica contains also the description of many microscopic organs and structures whose presence in different animal species is widely accepted, however their presence in humans is disputable. Typical examples are the haemal lymph nodes and haemal nodes, mentioned in the chapter Lymphoid organs which are secondary lymphoid organs found in many different mammalian species, but also in some birds. They are capable of performing haematopoietic and immunological functions but in the absence of lymphatic system pathology, no structures resembling haemal nodes / haemal lymph nodes have been detected in humans. Neurohaemal organs are mentioned within the chapter Endocrine system. Neurohaemal organs are known by different names, depending on the animal species studied, e.g. corpora allata or abdominal perisympathetic organs. To this date, these structures have been described in many different invertebrate species, but neurohaemal organs are also found in some lower vertebrates, in which the neurohaemal organ is referred to as "urophysis". According to our opinion, structures called neurohaemal organs in invertebrates are counterparts to circumventricular organs found in vertebrates, but cannot be named as such. Another somewhat controversial term mentioned in human histological nomenclature is the vomeronasal organ mentioned in the chapter Respiratory system. It is a specialized organ, which forms an integral supportive part of the olfaction of many mammalian species and reptiles. It is believed that the main function of vomeronasal organ is to regulate various behavioral aspects of intraspecies interaction by facilitating the detection of pheromones. The function and even existence of the vomeronasal organ in humans is a source of significant dispute among researchers. Some of them stated that vomeronasal organ disappears during fetal development, with except the vomeronasal duct. On the other hand, there are also authors who concluded that the vomeronasal organ is definitely present in adult humans. Similarly disputable question is the presence of multinucleated plasmodia in human body. This opinion article aims to open a wide scientific discussion concerning the importance and aptness of the inclusion of these terms in the human histological nomenclature despite they are probably exclusively zoological.
\end{abstract}

Keywords Terminologia Histologica $\cdot$ Histological nomenclature $\cdot$ Haemal lymph nodes $\cdot$ Neurohemal organ $\cdot$ Vomeronasal organ $\cdot$ Plasmodium versus syncytium

Ivan Varga

ivan.varga@fmed.uniba.sk

Extended author information available on the last page of the article

$\begin{array}{ll}\text { Abbreviations } \\ \text { FIPAT } & \begin{array}{l}\text { Federative International } \\ \text { Programme for Anatomical Terminology }\end{array} \\ \text { ICVHN } & \begin{array}{l}\text { International Committee } \\ \text { on Veterinary Histological Nomenclature }\end{array} \\ \text { TH } & \begin{array}{l}\text { Terminologia Histologica } \\ \text { vomeronasal organ }\end{array}\end{array}$

Programme for Anatomical Terminology

mittee

Terminologia Histologica

VNO vomeronasal organ 


\section{Introduction}

Terminology in morphological and zoological sciences is enormously important, similarly to its importance in human medical sciences. Proper denomination of individual structures of the animal / human body, whether from the perspective of gross anatomy, or from the microscopic point of view, has an irreplaceable role in unambiguous understanding and communication among scientists regardless of their field of expertise. The anatomical terminology dates back to ancient Greece and Rome, to more than two thousand and five hundred years ago. The end of the nineteenth century culminated in the first anatomical nomenclature, the Basiliensia Nomina Anatomica. Despite that, there was not a full consensus in the Latin anatomical nomenclature until as late as 1955. A new era with one worldwide fully accepted Latin nomenclature was eventually commenced by the publication of Parisiensia Nomina Anatomica. After that, several follow-up revisions were published to eventually reach the current last revision of the Latin anatomical nomenclature Terminologia Anatomica, issued by the Federative Committee on Anatomical Terminology and published in 1998 (Kachlik et al. 2008, 2015, 2016).

The initial knowledge of the microscopic structure of different animal / human bodies has been continuously broadening thanks to the development of new specialized staining and microscopic techniques, discovery of the electron microscope, or later application of methods of histochemistry and immunohistochemistry into routine tissue examination. This dynamics of knowledge accumulation inevitably brings the necessity of terms to describe and denominate these newly discovered structures. Because of this, 2008 can be considered a crucial year in this regard, because it was the year when the first internationally renowned human histology nomenclature Terminologia Histologica (TH) was published (FIPAT 2008). According to Allen (2009): "Terminologia Histologica contains terminology for cellular structures, tissue and organs at the microscopic level. The book present the Latin term for each structure accompanied by the term in current usage in English-speaking countries." Since the Terminologia Histologica is oriented exclusively to description of human cellular and tissue structures, there was also an urge to compile a similar nomenclature describing the microscopic structures within the animal kingdom, so in 2017 the first edition of internationally accepted veterinary histological nomenclature Nomina Histologica Veterinaria was published (ICVHN 2017).

The current version of the human Terminologia Histologica contains also the description of many microscopic organs and structures whose presence in different animal species is widely accepted, however their presence in humans is disputable. This opinion article aims to open a wide scientific discussion concerning the importance and aptness of the inclusion of these terms in the human histological nomenclature despite they are probably exclusively zoological.

\section{Material and methods}

A thorough, systematic and in-depth analysis of the current internationally accepted histology nomenclature "Terminologia Histologica: International Terms for Human Cytology and Histology "(FIPAT 2008). The analysis was focused on finding of those disputable structures, which are presumably present in animals, but are absent in humans. It is important to note that the opinions of different experts vary considerably.

\section{Results and discussion}

\section{Haemal lymph nodes and haemal nodes}

Haemal lymph nodes and haemal nodes, mentioned in the chapter Lymphoid organs of the $\mathrm{TH}$, are peculiar secondary lymphoid organs found in many different mammalian species, but also in some birds. They are capable of performing haematopoietic and immunological functions. These lymphoid organs were described in detail in water buffalos (Zidan and Pabst 2010), cattle (Cerutti et al. 1998; Zhang et al. 2013), goats (Bozkurt et al. 2018), dromedary camels (Zidan and Pabst 2004), pigs (Doboszyńska 2002; Akaydin and Kabak 2006), domestic yaks (Huang et al. 2019), roe deer (Akaydın Bozkurt et al. 2018) or rats (Castenholz and Castenholz 1996). In spite of that, these organs are in general not known to many immunologists, they are not mentioned in most immunological textbooks, and their presence in humans is controversial until today. What can possibly be considered as description of haemal lymph nodes in humans was published in 1884 by Gibbes who made an interesting discovery during a dissection of renal artery and vein in three human subjects. He described the microscopic structure of "small bodies which I at first thought were lymphatic glands" as follows: "The great peculiarity of this structure consists in these blood-vessels opening directly into the spaces between the cell masses and fibrous trabeculae". The conclusion of Gibbes (1884) was: "From the above it will be seen that I have found this peculiar gland, resembling a lymphatic gland somewhat, but having blood circulating in it instead of lymph in three cases, and these were consecutive; it would, therefore, seem to be a permanent structure". Apart from this, more than 130 years old, notion of human haemal lymph nodes, we did not find any scientific article mentioning haemal lymph nodes in humans in the PubMed database (PubMed comprises over 29 million citations for biomedical literature from MEDLINE, life science journals, and online books). 
Haemal lymph nodes and haemal nodes share structural and functional similarities with both the spleen and the lymph nodes. Their hypothetic functions are related to the storage and filtration of the blood, formation of blood cells and immunological defense (presence of secondary lymphoid follicles responsible for antibody production) (Akaydin and Kabak 2006; Zidan and Pabst 2004, 2010). Ezeasor et al. (1989) described the process of phagocytosis in haemal lymph nodes in caprine. Nevertheless, even the mechanism by which erythrocytes enter the parenchyma of the haemal node is still controversial (Zhang et al. 2013). Haemal lymph nodes and haemal nodes are dark to brown-red, small, bean-shaped or spherical encapsulated organs (2-12 $\mathrm{mm}$ in diameter), typically embedded in adipose tissue (Zidan and Pabst 2004). Anatomically they are localized alongside the inferior vena cava and abdominal aorta, near lymph nodes, and especially around blood vessels in the mediastinum, abdominal cavity, mesentery, and pelvic cavity (Akaydın Bozkurt et al. 2018). Goat haemal nodes house a large population of T- lymphocytes, B- lymphocytes, macrophages and S100-protein positive (probably dendritic) cells (Bozkurt et al. 2018).

The ambiguity of these organs is underlined by terminological inconsistency - haemal lymph nodes are sometimes mentioned only as a synonym for haemal nodes or blood containing lymph nodes (Bogacz et al. 2000). However, some researchers consider haemal nodes and haemal lymph nodes as individual entities. According to one definition, haemal nodes have no efferent or afferent lymph vessels and contain blood-filled sinusoid capillaries only. These are peculiar to ruminants (Zidan and Pabst 2010; Zhang et al. 2012) and pigs (Akaydin and Kabak 2006). On the other hand, haemal lymph nodes contain both afferent and efferent lymphatics, and both blood and lymph sinusoid capillaries within the parenchyma. They are typical in other mammals, such as rats (Castenholz and Castenholz 1996), or dromedary camels (even though camels are ruminants; Zidan and Pabst 2004). As we have already mentioned, this classification is not uniform, what is reflected for example in a work by Salazar (1984) who described "haemal lymph nodes which are separate from the lymphatic system" in bovine ruminants. According to previous definition, these described small lymphoid organs should be classified as "haemal nodes".

On top of the uncertainty regarding haemal nodes / haemal lymph nodes in animal species, their occurrence in humans is even more dubious. Besides the scarcity of human studies investigating haemal nodes / haemal lymph nodes, they are allegedly present only in disease state (with the exception of the abovementioned description by Gibbes from 1884). What is necessary to mention in this regard, is that extramedullary haematopoiesis may occur in axillary lymph nodes of breast carcinoma patients receiving neoadjuvant chemotherapy (Lytle et al. 2019; Badr et al. 2019) or during chronic myeloid leukemia (Devi et al. 2019). This can be potentially confusing for inexperienced histologists, since these pathologically altered lymph nodes may resemble haemal / haemal lymph nodes of other animals. In the absence of lymphatic system pathology, no structures resembling haemal nodes / haemal lymph nodes have been detected in humans in the proximity of splenic nodes (Bogacz et al. 2000). For these reasons, we deem the inclusion of haemal nodes / haemal lymph nodes in the Terminologia Histologica redundant.

\section{Neurohaemal organs}

Neurohaemal organs are mentioned in the TH within the chapter Endocrine system, in the following footnote reference: "This term originally introduced for organs in crustaceans in which neurosecretory fibres release hormones into the bloodstream - Cerlise DB, Knowles FGW. Neurohaemal organ in Crustaceans. Nature London 1953, 172: 404-405. Is now widely applied to similar organs in mammals, including humans." According to a recent description, neurohaemal organs represent a diverse set of organ-like structures of many invertebrate taxa. As the name suggests, these organs are found within the nervous tissue in the close vicinity of blood vessels. They comprise of dilated axonal endings, and a palette of various cell types, whose main function is to store and release neurosecretory substances directly into the bloodstream, along with many other functions. Neurohaemal organs are known by different names, depending on the animal species studied, e.g. corpora allata or abdominal perisympathetic organs (Predel and Gäde 2005). To this date, these structures have been described in many different species, from a wide variety of taxons ranging from the house cricket Acheta domesticus (Linnaeus, 1758)(Weber and Gaude 1971), through the soft tick Argas arboreus (Roshdy and Marzouk 1982), to the turnip moth Agrotis segetum (Denis \& Schiffermüller, 1775) (Cantera et al. 1992). Neurohaemal organs are also found in vertebrates, e.g. in cyprinid fish tor mahseer Tor tor (Hamilton, 1822) (Qureshi et al. 1978), and sturgeon Acipenser ruthenus (Linnaeus, 1758) (McMaster et al. 1992), in which the neurohaemal organ is referred to as "urophysis". Neurohaemal organs are sometimes very loosely defined, what can be problematic from the terminological point of view. Fortunately, Joly et al. (2007) published an excellent review paper titled rather poetically "Windows of the brain: towards a developmental biology of circumventricular and other neurohaemal organs". In this article, authors made in clear, that structures called neurohaemal organs in invertebrates are counterparts to circumventricular organs found in vertebrates, but cannot be named as such. The reason lies in the anatomical differences of the nervous systems between these two large taxons. While invertebrates have significantly less complicated structure of the nervous system composed largely of ganglia without anatomically defined ventricles, the brain of vertebrates is considerably more complex and 
contains system of brain ventricles (Joly et al. 2007). It follows that circumventricular organs found in vertebrates are functionally similar and closely related to neurohaemal organs of invertebrates, yet much more complicated in structure. Regarding the human neurohistology, it is debatable whether the circumventricular organs and neurohaemal organs can be considered as synonyms, or the term neurohaemal organ should be used exclusively in studies and textbooks on invertebrates.

\section{Vomeronasal organ}

The vomeronasal organ (VNO) is mentioned in the chapter Respiratory system, in the part concerning the histological description of the nasal cavity. The VNO is a specialized organ, which forms an integral supportive part of the olfaction of many animal species for example in brown bear (Tomiyasu et al. 2017), horse (Lee et al. 2016), giraffe (Kondoh et al. 2017), or even in mouse (Aland et al. 2016; Salazar et al. 2016) and reptiles (Mangiacotti et al. 2019). It is believed that the main function of vomeronasal organ is to regulate various behavioral aspects of intraspecies interaction by facilitating the detection of pheromones. In reptiles, the VNO is connected to lacrimal drainage system - the secretions of orbital gland flow into the nasolacrimal duct and then pass down to the VNO together with soluble pheromones from the air (Ali et al. 2019). Functional aspects of the human VNO are a subject of debate, because no accessory olfactory bulbs which receive information from the vomeronasal receptor cells are present (D'Aniello et al. 2017). Wessels et al. (2014) reported that the VNO has an endocrine function (rich capillary bed underlying VNO cells and secretion of calcium-binding protein).

VNO is also known as Jacobson's organ, an eponym which reflects a thorough documentation of this organ in many animal species by Ludwig Jacobson, Danish surgeon from the beginning of the nineteenth century. The first to describe the human VNO was a German scientist Samuel Thomas von Sömmerring in 1809 (Stoyanov and Matev 2018). In spite of that, the real existence of VNO in humans is controversial until today. On top of that, McGann (2017) denied the presence of the VNO in adult humans in an article "Poor human olfaction is a $19^{\text {th }}$-century-myth" published in the Nature journal. According to other authors, all structures of the VNO regress except the vomeronasal duct (Witt and Wozniak 2006), so the importance of this structure in human development may be questionable. Mladina et al. (2017) hypothesized that VNO could be the source of pneumatization of the nasal septum during human development. The orifice of the vomeronasal duct can be observed in about $2 / 3$ of the population at the junction between the cartilaginous septum and the vomer, $2 \mathrm{~cm}$ from the nares (visible as an invagination of the nasal mucosa). Especially otorhinolaryngologists may think about its presence during nasal endoscopy (Roussel et al. 2018).

While its presence in animals is well documented, its function and even existence in humans is a source of significant dispute among researchers. For example, Kjaer and Fischer Hansen (1996) stated that VNO disappears during fetal development. Apart from the literature cited, the vomeronasal organ is very nicely shown e.g. in the famous Hinrichsen's Embryology (Hinrichsen 1990) in the human embryo (26 mm, Carnegie stage 22). On the other hand, there are also authors, who think that the dispute regarding the presence/absence of the VNO in humans in totally out of question. Stoyanov et al. (2018) concluded, that the VNO is definitely present in adult humans during normal physiological conditions. The authors provided well illustrated figures underlining their conclusions. What the authors consider a definite proof of its genuine presence in humans is that this organ has been extensively documented from its discovery using different approaches including computed tomography and magnetic resonance imaging (Stoyanov et al. 2018). Other authors claim that the VNO might persist in some individuals while it does not in others and it is not certain at what age it regresses. For example, Trotier et al. (2000) found that a vomeronasal pit was present in up to $73 \%$ of individuals at some age. Falci et al. (2013) showed the association of the VNO with some pathologies. Would it really be advisable to remove a structure from the $\mathrm{TH}$ which is linked to pathological conditions in clinical medicine? In contrast, some authors stand the opinion that humans have no accessory apparatus aiding the olfaction whatsoever, including the VNO (Witt and Wozniak 2006; McGann 2017).

Despite the controversial nature of the VNO in humans, it is included in the official nomenclature Terminologia Histologica. It is worth considering whether its inclusion in the TH is appropriate, or it should be left out until the scientific community finds the consensus regarding its genuine presence in adult humans (and not only during prenatal development).

\section{Plasmodium versus syncytium in humans}

Plasmodium contains many nuclei, which are produced by dividing existing nuclei without subsequent cell division (cytokinesis). Plasmodia are best known from slime molds, but are also found in parasitic Myxosporea, and some algae, but not in humans. Interesting is the cell cycle of malaria parasites of the protozoan genus Plasmodium, since its parasitic form of replication leads to the formation of multinucleated host cells, such as the Plasmodium oocyst in the mosquito midgut or the Plasmodium schizont in human red blood cells. Parasite nuclear division is thus not immediately followed by host cell division (Arnot 2013). According to the mentioned description of plasmodium, we think that it should not be used in 
human histological terminology. The mechanism of human multinucleated cell formation is usually a matter of the fusion of originally mononucleated cells, resulting in a structure known as syncytium. The fusion of mononucleated myoblasts into multinucleate skeletal muscle fiber is one of the most typical examples of syncytium formation in the human body (Xie et al. 2017). Another examples of syncytia in the human body are multinucleated bone cells "osteoclasts", responsible for bone resorption (Jacome-Galarza et al. 2019), or syncytiotrophoblast during implantation and chorionic villi formation (Cierna et al. 2016). Also monocytes, a type of white blood cells, are able to undergo fusion to produce different types of multinucleated giant syncytial cells, such as Langhans cells in response to Mycobacterium tuberculosis (Koch, 1882) infection or foreign body giant cells in response to implanted biomaterials (Champion et al. 2018).Last but not least, it is necessary to mention that some cells in the human body are able to perform endomitosis without subsequent cytokinesis, resulting in cells possessing two nuclei (hepatocytes, urothelial umbrella cells, cardiac muscle cells) (Gentric et al. 2012; Polák et al. 2012; Miko et al. 2017). The term "binucleated cell (cellula binucleata)" is already included in TH, at the beginning of the chapter Cytology. In contrast to plasmodium formation which results in multiple nuclei (more than three), cells resulting from this process contain exactly two nuclei, so these processes cannot be considered alike.

\section{Conclusion and further perspectives}

Any new terminological suggestion supported with reference, citations, figures can be send to the FIPAT either by individuals or gathered by National Anatomical Scientific Society. Any new histological experiment using laboratory animals has to be verified also in humans before this new knowledge can be implemented into the TH. One example is a new discovery of sublayers within the external layer of arteries (superficial to tunica media), described by Witter et al. (2017) in pigs, cats and dogs. This knowledge can be also beneficial for human vascular surgery, but it is crucial to verify this knowledge in humans before implementation into clinical practice. We hope that a wide scientific discussion will develop before the publication of the second edition, so perhaps the mentioned controversies regarding the zoological terms will be settled and the new edition of the TH will become truly an internationally accepted communication tool for all human histologists. The aim of this opinion article is to draw attention to expert discussion which would initiate and finally resolve the issue of the presence of these organs in humans. If the conclusion of such discussion will be negative, it would be appropriate to remove them from the next edition of the Terminologia Histologica. Alternatively, there is also a possibility to add the veterinary terms also to the human Terminologia Histologica, however, it would be necessary to mark them, e.g. with a \# or *, or in a different color.

\section{Compliance with ethical standards}

Conflict of interest The authors declare that they have no conflict of interest.

\section{References}

Akaydın Bozkurt Y, Karada ğ Sarı E, Kabak M (2018) Immunohistochemical study on roe deer haemal nodes. Folia Morphol (Warsz) 77(2):266-271. https://doi.org/10.5603/FM. a2017.0103

Akaydin Y, Kabak M (2006) First description and morphology of haemal nodes in piglets (Sus scrofa domestica). Acta Vet Hung 54(2):135142

Aland RC, Gosden E, Bradley AJ (2016) Seasonal morphometry of the vomeronasal organ in the marsupial mouse, Antechinus subtropicus. J Morphol 277(11):1517-1530. https://doi.org/10.1002/jmor.20593

Ali MJ, Rehorek SJ, Paulsen F (2019) A major review on disorders of the animal lacrimal drainage systems: evolutionary perspectives and comparisons with humans. Ann Anat 224:102-112. https://doi.org/ 10.1016/j.aanat.2019.04.003

Allen WE (2009) Terminologia anatomica: international anatomical terminology and Terminologia Histologica: international terms for human cytology and histology. J Anat 215(2):221. https://doi.org/10. 1111/j.1469-7580.2009.01093 1.x

Arnot DE (2013) Cell cycle regulation in Plasmodium. Encyclopedia of Malaria. Springer Science + Business Media, New York. https://doi. org/10.1007/978-1-4614-8757-9_43-1

Badr NM, Roberts C, Shaaban AM (2019) Extramedullary haematopoiesis in axillary lymph nodes of breast carcinoma patients receiving neoadjuvant chemotherapy: a potential diagnostic pitfall. Pathobiology 86(2-3):167-172. https://doi.org/10.1159/000493752

Bogacz K, Slusarczyk K, Bibułek-Bogacz A (2000) Attempt to identify hemolymph nodes in humans. Med Sci Monit 6(6):1082-1084

Bozkurt YA, Kabak M, Bașak F, Onuk B (2018) The localization of CD3, CD79a, CD68 and S100 protein immunoreactive cells in hemal nodes of Saanen goat (Capra hircus). Biotech Histochem 93(7): 536-540. https://doi.org/10.1080/10520295.2018.1479886

Cantera R, Hansson BS, Hallberg E, Nässel DR (1992) Postembryonic development of leucokinin I-immunoreactive neurons innervating a neurohemal organ in the turnip moth Agrotis segetum. Cell Tissue Res 269(1):65-77

Castenholz HI, Castenholz A (1996) Fluorescence microscopic studies on hemal lymph nodes in rats: a new immunobiological concept. Lymphology 29(4):141-150

Cerlise DB, Knowles FGW (1953) Neurohaemal organ in crustaceans. Nature (London) 172:404-405

Cerutti P, Marcaccini A, Guerrero F (1998) A scanning and immunohistochemical study in bovine haemal node. Anat Histol Embryol 27(6):387-392

Champion TC, Partridge LJ, Ong SM, Malleret B, Wong SC, Monk PN (2018) Monocyte subsets have distinct patterns of tetraspanin expression and different capacities to form multinucleate giant cells. Front Immunol 9:1247. https://doi.org/10.3389/fimmu.2018.01247

Cierna Z, Varga I, Danihel L Jr, Kuracinova K, Janegova A, Danihel L (2016) Intermediate trophoblast - a distinctive, unique and often unrecognized population of trophoblastic cells. Ann Anat 204:4550. https://doi.org/10.1016/j.aanat.2015.10.003 
D'Aniello B, Semin GR, Scandurra A, Pinelli C (2017) The vomeronasal organ: a neglected organ. Front Neuroanat 11:70. https://doi.org/10. 3389/fnana.2017.00070

Devi D, Keloth T, Manivannan P, Gochhait D, Kekade S, Gudivada V, Siddaraju N (2019) Cytology of extramedullary haematopoiesis-a rare unanticipated finding in the lymph node of an undiagnosed chronic myeloid leukaemia case. Cytopathology 30(4):436-439. https://doi.org/10.1111/cyt.12683

Doboszyńska T (2002) The connections of lymphatic vessels draining female reproductive organs with lymphnodes in the pig. Pol J Vet Sci 5(1):29-34

Ezeasor DN, Singh A, Sims DE (1989) Erythrophagocytosis in the caprine hemal node. Acta Anat (Basel) 134(4):341-345

Falci SG, Verli FD, Consolaro A, Santos CR (2013) Morphological characterization of the nasopalatine region in human fetuses and its association to pathologies. J Appl Oral Sci 21(3):250-255. https://doi. org/10.1590/1679-775720130008

FIPAT (2008) Terminologia Histologica: international terms for human cytology and histology. Lippincott Williams \& Wilkins, Baltimore

Gentric G, Desdouets C, Celton-Morizur S (2012) Hepatocytes polyploidization and cell cycle control in liver physiopathology. Int J Hepatol 2012:282430. https://doi.org/10.1155/2012/282430

Gibbes H (1884) On some structures found in the connective tissue between the renal artery and vein in the human subject. Q J Microsc Sci 24:186-190

Hinrichsen KV (ed) (1990) Humanembryologie. Lehrbuch und Atlas der vorgeburtlichen Entwicklung des Menschen. Springer Verlag, Berlin

Huang Y, Cui Y, Yu S, He J, He Y, Zhang Q, Liu P, Pu Y, Sun J, Kang X (2019) Comparison of histological characteristics and expression of CD3 and CD79a among the hemal nodes, lymph nodes and spleens of yaks (Bos grunniens). Histol Histopathol 34(3):241-256. https:// doi.org/10.14670/HH-18-030

ICVHN (2017) Nomina Histologica Veterinaria. http://www.wava-amav. org/wava-documents.html. Accessed 08 March 2019

Jacome-Galarza CE, Percin GI, Muller JT, Mass E, Lazarov T, Eitler J, Rauner M, Yadav VK, Crozet L, Bohm M, Loyher PL, Karsenty G, Waskow C, Geissmann F (2019) Developmental origin, functional maintenance and genetic rescue of osteoclasts. Nature 568(7753): 541-545. https://doi.org/10.1038/s41586-019-1105-7

Joly JS, Osório J, Alunni A, Auger H, Kano S, Rétaux S (2007) Windows of the brain: towards a developmental biology of circumventricular and other neurohemal organs. Semin Cell Dev Biol 18(4):512-524. https://doi.org/10.1016/j.semcdb.2007.06.001

Kachlik D, Baca V, Bozdechova I, Cech P, Musil V (2008) Anatomical terminology and nomenclature: past, present and highlights. Surg Radiol Anat 30(6):459-466. https://doi.org/10.1007/s00276-0080357-y

Kachlik D, Musil V, Baca V (2015) Terminologia Anatomica after 17 years: inconsistencies, mistakes and new proposals. Ann Anat 201: 8-16. https://doi.org/10.1016/j.aanat.2015.04.006

Kachlik D, Musil V, Baca V (2016) Contribution to the anatomical nomenclature concerning general anatomy and anatomical variations. Surg Radiol Anat 38(7):757-765. https://doi.org/10.1007/s00276016-1627-8

Kjaer I, Fischer Hansen B (1996) The human vomeronasal organ: prenatal developmental stages and distribution of luteinizing hormonereleasing hormone. Eur J Oral Sci 104(1):34-40. https://doi.org/ 10.1111/j.1600-0722.1996.tb00043.x

Kondoh D, Nakamura KG, Ono YS, Yuhara K, Bando G, Watanabe K, Horiuchi N, Kobayashi Y, Sasaki M, Kitamura N (2017) Histological features of the vomeronasal organ in the giraffe, Giraffa camelopardalis. Microsc Res Tech 80(6):652-656. https:// doi.org/10.1002/jemt.22843

Lee KH, Park C, Kim J, Moon C, Ahn M, Shin T (2016) Histological and lectin histochemical studies of the vomeronasal organ of horses.
Tissue Cell 48(4):361-369. https://doi.org/10.1016/j.tice.2016.05. 002

Lytle A, Schnabel F, Ozerdem U (2019) Incidental extramedullary hematopoiesis of an axillary lymph node: a diagnostic pitfall in sentinel lymph node biopsy. Breast J 2019. https://doi.org/10.1111/tbj.13404

Mangiacotti M, Fumagalli M, Cagnone M, Viglio S, Bardoni AM, Scali S, Sacchi R (2019) Morph-specific protein patterns in the femoral gland secretions of a colour polymorphic lizard. Sci Rep 9(1):8412. https://doi.org/10.1038/s41598-019-44889-7

McGann JP (2017) Poor human olfaction is a 19th-century myth. Science 356(6338): eaam7263. https://doi.org/10.1126/science.aam7263

McMaster D, Belenky MA, Polenov AL, Lederis K (1992) Isolation and amino acid sequence of urotensin II from the sturgeon Acipenser ruthenus. Gen Comp Endocrinol 87(2):275-285

Miko M, Kyselovič J, Danišovič L', Barczi T, Polák Š, Varga I (2017) Two nuclei inside a single cardiac muscle cell. More questions than answers about the binucleation of cardiomyocytes. Biologia 72(8): 825-830. https://doi.org/10.1515/biolog-2017-0107

Mladina R, Antunović R, Cingi C, Bayar Muluk N, Skitarelić N (2017) Sinus septi nasi: anatomical study. Clin Anat 30(3):312-317. https:// doi.org/10.1002/ca.22850

Polák Š, Žiaran S, Mištinová J, Bevízová K, Danišovič L', Varga I (2012) Options for histological study of the structure and ultrastructure of human urinary bladder epithelium. Biologia 67(5):1018-1025. https://doi.org/10.2478/s11756-012-0090-1

Predel R, Gäde G (2005) Peptidomics of neurohemal organs from species of the cockroach family Blattidae: how do neuropeptides of closely related species differ? Peptides 26(1):3-9

Qureshi MA, Swarup H, Qureshi TA (1978) Caudal neurosecretory system and the neurohemal organ of Tor tor (ham.). Anat Anz 143(2): 183-191

Roshdy MA, Marzouk AS (1982) The subgenus Persicargas (Ixodoidea: Argasidae: Argas). 36. Structure and postembryonic development of the neurohemal organ in a. (P.) arboreus. Z Parasitenkd 66(3):345351

Roussel LM, Escalard C, Hitier M (2018) The forgotten organ. Eur Ann Otorhinolaryngol Head Neck Dis 135(2):143-144. https://doi.org/ 10.1016/j.anorl.2017.10.003

Salazar I (1984) The relation of the lymphatic system to hemolymph nodes in the sheep. Lymphology 17(2):46-49

Salazar I, Barrios AW, SáNchez-Quinteiro P (2016) Revisiting the vomeronasal system from an integrated perspective. Anat Rec (Hoboken) 299(11):1488-1491. https://doi.org/10.1002/ar.23470

Stoyanov GS, Matev BK (2018) Samuel Thomas von Sömmerring's contributions on the cranial nerves and vomeronasal organ. Cureus 10(6):e2859. https://doi.org/10.7759/cureus.2859

Stoyanov GS, Matev BK, Valchanov P, Sapundzhiev N, Young JR (2018) The human vomeronasal (Jacobson's) organ: a short review of current conceptions, with an English translation of Potiquet's original text. Cureus 10(5):e2643. https://doi.org/10.7759/cureus.2643

Tomiyasu J, Kondoh D, Sakamoto H, Matsumoto N, Sasaki M, Kitamura N, Haneda S, Matsui M (2017) Morphological and histological features of the vomeronasal organ in the brown bear. J Anat 231(5): 749-757. https://doi.org/10.1111/joa.12673

Trotier D, Eloit C, Wassef M, Talmain G, Bensimon JL, Døving KB, Ferrand J (2000) The vomeronasal cavity in adult humans. Chem Senses 25(4):369-380

Weber W, Gaude H (1971) Ultrastructure of the neurohemal organ in the nervus corporis allati II in Acheta domesticus. Z Zellforsch Mikrosk Anat 121(4):561-572

Wessels Q, Hoogland PV, Vorster W (2014) Anatomical evidence for an endocrine activity of the vomeronasal organ in humans. Clin Anat 27(6):856-860. https://doi.org/10.1002/ca.22382

Witt M, Wozniak W (2006) Structure and function of the vomeronasal organ. In: Hummel T, Welge-Lüssen a (eds). Taste and smell. An 
update. Adv Otorhinolaryngol, vol 63, Karger, Basel pp 70-83. https://doi.org/10.1159/000093751

Witter K, Tonar Z, Schöpper H (2017) How many layers has the adventitia? - structure of the arterial tunica externa revisited. Anat Histol Embryol 46(2):110-120. https://doi.org/10.1111/ahe.12239

Xie X, Wu SP, Tsai MJ, Tsai S (2017) The role of COUP-TFII in striated muscle development and disease. Curr Top Dev Biol 125:375-403. https://doi.org/10.1016/bs.ctdb.2016.12.006

Zhang W, Yasuda M, Hosaka YZ, Nasu T (2013) Scanning electron microscopic study of the vascular system in the hemal node of the bovine cervical region. J Vet Med Sci 75(1):79-83

Zhang W, Nasu T, Hosaka YZ, Yasuda M (2012) Comparative studies on the distribution and population of immunocompetent cells in bovine hemal node, lymph node and spleen. J Vet Med Sci 74(4): 405-411. https://doi.org/10.1292/jvms.11-0405

Zidan M, Pabst R (2004) Histological, histochemical and immunohistochemical study of the haemal nodes of the dromedary camel. Anat Histol Embryol 33(5):284-289

Zidan M, Pabst R (2010) Histology of hemal nodes of the water buffalo (Bos bubalus). Cell Tissue Res 340(3):491-496. https://doi.org/10. 1007/s00441-010-0962-z

Publisher's note Springer Nature remains neutral with regard to jurisdictional claims in published maps and institutional affiliations.

\section{Affiliations}

\section{Ivan Varga ${ }^{1} \cdot$ Luuboš Danišovič $^{2} \cdot$ David Kachlík $^{3} \cdot$ Radoslav Beňuš $^{4} \cdot$ Martin Klein $^{1}$}

1 Institute of Histology and Embryology, Faculty of Medicine, Comenius University in Bratislava, Špitálska 24, SK81372 Bratislava, Slovakia

2 Institute of Medical Biology, Genetics and Clinical Genetics, Faculty of Medicine, Comenius University in Bratislava, Špitálska 24, SK81372 Bratislava, Slovakia
3 Department of Anatomy, Second Faculty of Medicine, Charles University, U Nemocnice 3, CZ-128 00 Prague, Czech Republic

4 Department of Anthropology, Faculty of Natural Sciences, Comenius University in Bratislava, Ilkovičova 6, SK84215 Bratislava, Slovakia 